Article

\title{
A Comparative Study of Scenedesmus dimorphus Cultured with Synthetic and Actual Wastewater
}

\author{
Liang $\mathrm{Li}^{*}$ and Kun Chi
}

check for updates

Citation: Li, L.; Chi, K. A

Comparative Study of Scenedesmus dimorphus Cultured with Synthetic and Actual Wastewater. Water 2021 13, 3060. https://doi.org/10.3390/ w13213060

Academic Editor: Antonio Zuorro

Received: 23 September 2021

Accepted: 26 October 2021

Published: 2 November 2021

Publisher's Note: MDPI stays neutral with regard to jurisdictional claims in published maps and institutional affiliations.

Copyright: (c) 2021 by the authors. Licensee MDPI, Basel, Switzerland. This article is an open access article distributed under the terms and conditions of the Creative Commons Attribution (CC BY) license (https:/ / creativecommons.org/licenses/by/ $4.0 /)$.
Guangzhou Chuangjing Municipal Engineering Design Co., Ltd., Guangzhou 510000, China; chikun2010@126.com

* Correspondence: liliang2020gzcj@126.com

Abstract: This study compared the growth of the microalgae Scenedesmus dimorphus in synthetic wastewater and actual wastewater under different cultivation conditions, in terms of nitrogen and phosphorus availability, wastewater quality, light condition and $\mathrm{CO}_{2}$ addition. The results show that the form of nitrogen source had a significant effect on the growth of microalgae. Urea as a nitrogen source increased the growth rate of $S$. dimorphus significantly, while the high concentration of inorganic nitrogen inhibited the growth. When phosphate was $4 \mathrm{mg} / \mathrm{L}$ and $\mathrm{pH}$ was 7 , the growth of $S$. dimorphus was the greatest. The bacteria in actual wastewater not only promote the growth of microalgae but also facilitate the formation of flocs, which is conducive to biomass harvest. With the increase in light intensity and light duration, S. dimorphus showed primarily an increasing and then a decreasing trend. Higher light intensity was required in actual wastewater than in synthetic wastewater, which may be due to the barrier effect of wastewater turbidity. S. dimorphus grew well in both kinds of wastewater with the addition of $2 \% \mathrm{CO}_{2}$.

Keywords: Scenedesmus dimorphus; synthetic wastewater; actual wastewater; nutrient source; light condition

\section{Introduction}

Water scarcity and environmental degradation have caused widespread concern about wastewater treatment and disposal worldwide. Urban wastewater treatment technologies can effectively prevent aquatic pollutants produced by human activities from entering natural water bodies [1]. Common treatment processes can effectively remove organic matter and suspended solids (SS), but the removal effect of nitrogen and phosphorus is limited [1,2]. In addition, conventional technologies have several problems such as high operating costs, large floor space, and difficulty in sludge disposal, etc. [2,3]. Therefore, it is necessary to explore an efficient and environmentally friendly wastewater treatment technology to replace traditional technologies.

Microalgae are a kind of single-celled microorganism that exist widely in aquatic environments. Microalgae can utilize carbon, nitrogen, and phosphorus as the main nutrients to maintain their growth [4]. Compared with the traditional biological treatment process, the microalgae treatment process can reduce the concentration of organic matter, nitrogen, phosphorus, heavy metals, and other substances in wastewater [5-7]. Microalgae also capture and utilize carbon dioxide through photosynthesis [8]. Meanwhile, the microalgae biomass cultured in wastewater can be converted into animal feed [9], biodiesel [10,11], biological fertilizer [12], and other substances [13,14] for resource utilization. The application of microalgae in wastewater treatment can not only achieve the removal of nutrients but also recover biomass for resource utilization, which has promising application prospects in the future.

The growth of microalgae in wastewater is influenced by various biological and abiotic factors, such as nutrients, original microorganisms, light condition, and $\mathrm{CO}_{2}$ concentration, etc. [15]. Previous studies have shown that there is a symbiotic relationship between 
microalgae and bacteria, effectively facilitating the growth rate and nutrient removal efficiency of microalgae [16]. In the microalgae-bacteria symbiotic system of wastewater culture, the aerobic microorganisms can remove more than $60 \% \mathrm{COD}$, while the microalgae can provide $\mathrm{O}_{2}(6 \mathrm{mg} / \mathrm{L})$ through photosynthesis, and remove $40 \%$ nitrogen $\left(\mathrm{NH}_{4}{ }^{+}-\mathrm{N}\right)$ and more than $90 \%$ phosphorus [17]. The concentration of nitrogen and phosphorus and other nutrients in wastewater can affect the purification efficiency of microalgae and the recovery effect of microalgae biomass. Hulya and Ilgi [18] reported that the removal efficiency of nitrogen and phosphorus was mainly affected by the concentration of influent ammonia nitrogen. Arumugam et al. [19] found that $S$. bijugatus grew better under the concentration of 5-10 mM nitrogen than that of $15-20 \mathrm{mM} . \mathrm{CO}_{2}$ and light intensity are also important factors to promote the efficiency of photosynthesis, so as to improve the uptake of nutrients by microalgae, and then increase the biomass accumulation [20]. Goncalves et al. [21] found that the growth and $\mathrm{CO}_{2}$ fixation rates of four microalgae strains (i.e., C. vulgaris, P. subcapitata, S. salina, and M. aeruginosa) all showed a trend of first increasing and then decreasing under different concentrations of $\mathrm{CO}_{2}$. The optimum $\mathrm{CO}_{2}$ concentration ranges between $4.87 \%$ and $5.62 \%$, and the maximum biomass can reach $0.126 \mathrm{~g} \mathrm{dw} / \mathrm{L} \cdot \mathrm{D}$. Shih-hsin et al. [22] found that with the increase in light intensity, the specific growth rate of $S$. obliquus primarily went up and then gradually stabilized, while biomass productivity and $\mathrm{CO}_{2}$ fixation rate first increased to the maximum value and then decreased significantly. Under $420 \mu \mathrm{mol} / \mathrm{m}^{2} \cdot \mathrm{s}$. light intensity, the maximum biomass yield and $\mathrm{CO}_{2}$ fixation rate were $840.56 \mathrm{mg} / \mathrm{L} \cdot \mathrm{d}$ and $1435.90 \mathrm{mg} / \mathrm{L} \cdot \mathrm{d}$, respectively. Lee, C. S. et al. [23] reported that the efficiency of nitrogen and phosphorus removal in a microalgae-heterotrophic bacteria system was negatively correlated with the dark duration. The chlorophyll a content and cell dry weight were the highest under a $12 \mathrm{~h}: 12 \mathrm{~h}$ lightdark photoperiod. Under the condition of a long period of light, the removal efficiency of nitrogen and phosphorus by microalgae and bacteria was high, and the biomass of microalgae reached the maximum. Therefore, it is necessary to investigate the effects of different cultural conditions on the growth of microalgae.

The objective of this study was to compare the effects of different culture conditions on the growth of Scenedesmus dimorphus in synthetic and actual wastewater. Using singlefactor and uniform-design experiments, the growth of S. dimorphus in synthetic wastewater under different forms and concentrations of nitrogen and phosphorus sources was first investigated, and then the interaction between wastewater quality and bacteria on the growth of $S$. dimorphus in actual wastewater was investigated. Finally, the effects of light conditions and $\mathrm{CO}_{2}$ on the cultivation of $S$. dimorphus were studied.

\section{Materials and Methods}

\subsection{Microalgae Strain and Culture}

The microalgae strain Scenedesmus dimorphus (FACHB-959) used in this study was purchased from the Freshwater Algae Culture Collection at the Institute of Hydrobiology (Wuhan, China, FACHB). S. dimorphus was cultured in a 3N-BBM + V medium (Bold Basal Medium with 3-fold Nitrogen and Vitamins; modified). Each liter of medium consists of the following: $\mathrm{NaNO}_{3} 0.75 \mathrm{~g}, \mathrm{CaCl}_{2} \cdot 2 \mathrm{H}_{2} \mathrm{O} 0.025 \mathrm{~g}, \mathrm{MgSO}_{4} \cdot 7 \mathrm{H}_{2} \mathrm{O} 0.075 \mathrm{~g}, \mathrm{~K}_{2} \mathrm{HPO}_{4} \cdot 3 \mathrm{H}_{2} \mathrm{O}$ $0.075 \mathrm{~g}, \mathrm{KH}_{2} \mathrm{PO}_{4} 0.175 \mathrm{~g}, \mathrm{NaCl} 0.025 \mathrm{~g}$, trace element mixed liquor $6 \mathrm{~mL}$, Vitamin $\mathrm{B}_{1}$ $(1.2 \mathrm{~g} / \mathrm{L}) 1 \mathrm{~mL}$, Vitamin $B_{12}(1.0 \mathrm{~g} / \mathrm{L}) 1 \mathrm{~mL}$, and distilled water. The trace element mixed liquor contained: $\mathrm{Na}_{2}$ EDTA $0.75 \mathrm{~g}, \mathrm{FeCl}_{3} \cdot 6 \mathrm{H}_{2} \mathrm{O} 97 \mathrm{mg}, \mathrm{MnCl}_{2} \cdot 4 \mathrm{H}_{2} \mathrm{O} 41 \mathrm{mg}, \mathrm{ZnCl}_{2} \cdot 6 \mathrm{H}_{2} \mathrm{O}$ $5.0 \mathrm{mg}, \mathrm{CoCl}_{2} \cdot 6 \mathrm{H}_{2} \mathrm{O} 2.0 \mathrm{mg}, \mathrm{Na}_{2} \mathrm{MoO}_{4} \cdot 2 \mathrm{H}_{2} \mathrm{O} 4.0 \mathrm{mg}$, and distilled water $1000 \mathrm{~mL}$. The strain was incubated in a $250 \mathrm{~mL}$ conical flask in a light incubator at $20{ }^{\circ} \mathrm{C}$ and exposed to a weak light condition ( 1000 lux, $12 \mathrm{~h}$ light $/ 12 \mathrm{~h}$ dark). The strain was transferred every 2-3 months in a sterile environment. The enlargement conditions were at $25 \pm 1{ }^{\circ} \mathrm{C}$ and a continuous light of 2000-4000 lux for a transfer cycle of 7-14 d. The flasks were shaken regularly 2-3 times a day to replenish the carbon dioxide needed for growth.

The formula of synthetic wastewater used for this study is shown in Table 1. The water quality parameters of the synthetic wastewater are shown in Table 2. 
Table 1. The formula of synthetic wastewater.

\begin{tabular}{cc}
\hline Medium Composition & Consumption \\
\hline soluble starch $(\mathrm{g})$ & 0.10 \\
urea $(\mathrm{g})$ & 0.15 \\
$\mathrm{MgSO}_{4} \cdot 7 \mathrm{H}_{2} \mathrm{O}(\mathrm{g})$ & 0.075 \\
$\left.\mathrm{NH}_{4}\right)_{2} \mathrm{SO}_{4}(\mathrm{~g})$ & 0.075 \\
$\mathrm{NaHCO}_{3}(\mathrm{~g})$ & 0.30 \\
$\mathrm{~K}_{2} \mathrm{HPO}_{4} \cdot 2 \mathrm{H}_{2} \mathrm{O}(\mathrm{mg} / \mathrm{L})$ & 0.05 \\
$\mathrm{FeCl}_{3}(1 \%)(\mathrm{mL})$ & 0.15 \\
milk powder $(\mathrm{g})_{\text {tap water }(\mathrm{mL})}$ & 0.2 \\
\end{tabular}

Table 2. The water quality parameters of the synthetic wastewater.

\begin{tabular}{cc}
\hline Water Quality Index & Concentration \\
\hline $\mathrm{pH}$ & $7.4-8.0$ \\
$\mathrm{SS}(\mathrm{mg} / \mathrm{L})$ & 98 \\
$\mathrm{COD}(\mathrm{mg} / \mathrm{L})$ & $340-400$ \\
$\mathrm{NH}_{4}^{+}-\mathrm{N}(\mathrm{mg} / \mathrm{L})$ & $10-15$ \\
$\mathrm{TN}(\mathrm{mg} / \mathrm{L})$ & $70-80$ \\
$\mathrm{TP}(\mathrm{mg} / \mathrm{L})$ & $5-7$ \\
\hline
\end{tabular}

The actual municipal wastewater was obtained from the Shenzhen Buji wastewater treatment plant in Guangdong, China. The primary sedimentation tank (PT) wastewater was taken from the grit chamber and settled for $30 \mathrm{~min}$; the secondary sedimentation tank (ST) wastewater was taken directly from the outlet of the secondary sedimentation tank. The main characteristics of PT wastewater and ST wastewater are shown in Table 3.

Table 3. The main characteristics of PT wastewater and ST wastewater.

\begin{tabular}{ccc}
\hline Water Quality Index & Concentration in PT Wastewater & Concentration in ST Wastewater \\
\hline $\mathrm{pH}$ & 7.8 & 7.9 \\
$\mathrm{SS}(\mathrm{mg} / \mathrm{L})$ & 122 & 34 \\
$\mathrm{COD}(\mathrm{mg} / \mathrm{L})$ & 188 & 45.6 \\
$\mathrm{NH}_{4}{ }^{-}-\mathrm{N}(\mathrm{mg} / \mathrm{L})$ & 46.5 & 23.2 \\
$\mathrm{NO}_{3}{ }^{-}-\mathrm{N}(\mathrm{mg} / \mathrm{L})$ & 0.8 & 7.3 \\
$\mathrm{NO}_{2}{ }^{-}-\mathrm{N}(\mathrm{mg} / \mathrm{L})$ & 0.375 & 0 \\
$\mathrm{TP}(\mathrm{mg} / \mathrm{L})$ & 2.77 & 2 \\
\hline
\end{tabular}

\subsection{Analytical Methods}

The growth of microalgae was expressed in terms of optical density and chlorophyll a content, depending on the effluent quality used in this study. The optical density was measured at $680 \mathrm{~nm}$ by the spectrophotometer $\left(\mathrm{OD}_{680}\right)$, and the growth curve of microalgae was expressed as its optical density versus time. Microalgal growth could also be estimated using the specific growth rate, as shown in Equation (1).

$$
\mu=\ln \left(\mathrm{N}_{2} / \mathrm{N}_{1}\right) / \mathrm{t}
$$

where $\mu$ is the specific growth rate, $N_{1}$ and $N_{2}$ are the initial and final $O_{680}$ value, and $t$ is the cultivation time (d).

Chlorophyll a content was determined by the hot ethanol extraction method [24]. Briefly, approximately $10 \mathrm{~mL}$ of the sample was extracted through a $0.45 \mu \mathrm{m}$ microporous membrane and then frozen at $-20{ }^{\circ} \mathrm{C}$ for $12 \mathrm{~h}$. Subsequently, $7 \mathrm{~mL}$ of pre-warmed $90 \%$ ethanol was added and extracted for $2 \mathrm{~min}$ in a water bath at $80^{\circ} \mathrm{C}$. The extract was shaken with ultrasound for $10 \mathrm{~min}$ and set in the dark for 4-6 h, filtered and then diluted to $25 \mathrm{~mL}$. The absorbance values at $665 \mathrm{~nm}$ and $750 \mathrm{~nm}$ were measured with $90 \%$ ethanol 
as a reference. After acidification with $1 \mathrm{~mol} / \mathrm{L}$ hydrochloric acid, the extract was shaken adequately and stood for $15 \mathrm{~min}$, and the absorbance values at $665 \mathrm{~nm}$ and $750 \mathrm{~nm}$ were read again. The chlorophyll a content was calculated as shown in Equation (2).

$$
\mathrm{C}=27.9 \times \mathrm{V}_{\mathrm{m}}\left[\left(\mathrm{E}_{665}-\mathrm{E}_{750}\right)-\left(\mathrm{A}_{665}-\mathrm{A}_{750}\right)\right] / \mathrm{V}_{\mathrm{s}}
$$

where $C$ is the chlorophyll a content $\left(\mathrm{mg} / \mathrm{m}^{3}\right), \mathrm{V}_{\mathrm{m}}$ is the ethanol volume $(\mathrm{mL}), \mathrm{V}_{\mathrm{s}}$ is the sample volume (L), $\mathrm{E}_{665}$ and $\mathrm{E}_{750}$ are the absorbance values at $665 \mathrm{~nm}$ and $750 \mathrm{~nm}$ after extraction, and $A_{665}$ and $A_{750}$ are the absorbance value at $665 \mathrm{~nm}$ and $750 \mathrm{~nm}$ after acidification.

\subsection{Experimental Design}

\subsubsection{The Effect of Nutrients in Synthetic Wastewater}

A series of batch tests were conducted to explore the effects of different nitrogen sources and concentrations on the growth of $S$. dimorphus. The sources of $\mathrm{NH}_{4}{ }^{+}-\mathrm{N}, \mathrm{NO}_{3}{ }^{-}-\mathrm{N}$, urea $\left(\mathrm{CH}_{4} \mathrm{~N}_{2} \mathrm{O}\right)$, and mixed nitrogen were $\left(\mathrm{NH}_{4}\right)_{2} \mathrm{SO}_{4}, \mathrm{NaNO}_{3}$, urea, and synthetic wastewater, respectively. Each was set at three nitrogen concentrations of $20 \mathrm{mg} / \mathrm{L}, 40 \mathrm{mg} / \mathrm{L}$, and $85 \mathrm{mg} / \mathrm{L}$. The initial $\mathrm{pH}$ of inoculation was 7 , and the subsequent $\mathrm{pH}$ was no longer adjusted. The growth curve of $S$. dimorphus was measured for 8 days. In addition, $\mathrm{OD}_{680}$ on day 4 and chlorophyll a content on day 3 were measured. Additionally, then a repeatable two-factor ANOVA was performed.

Since $\mathrm{pH}$ affects the phosphorus forms in the aquatic environment [25], the interaction between $\mathrm{pH}$ and phosphorus concentration needs to be explored. The effects of phosphorus concentration and $\mathrm{pH}$ on the growth of $\mathrm{S}$. dimorphus were investigated by uniform experimental design. The experimental scheme is shown in Table 4. Phosphorus concentration was set at $2 \mathrm{mg} / \mathrm{L}, 4 \mathrm{mg} / \mathrm{L}, 6 \mathrm{mg} / \mathrm{L}$, and $8 \mathrm{mg} / \mathrm{L}$. The $\mathrm{pH}$ value was set to $4-11.5 \% \mathrm{KOH}$ and $10 \% \mathrm{CH}_{3} \mathrm{COOH}$ solution was used to adjust the $\mathrm{pH}$ value to the set value every $12 \mathrm{~h}$. The growth curve of $S$. dimorphus was measured for 7 days. The cubic polynomial stepwise regression equation was fitted to the $\mathrm{OD}_{680}$ of microalgae cultured for 4 days.

Table 4. The uniform design of the effects of phosphorus concentration and $\mathrm{pH}$ on Scenedesmus dimorphus growth.

\begin{tabular}{ccc}
\hline Group & Phosphorus Concentration $(\mathbf{m g} / \mathbf{L})$ & pH \\
\hline 1 & 2.0 & 5.0 \\
2 & 2.0 & 9.0 \\
3 & 4.0 & 7.0 \\
4 & 4.0 & 11.0 \\
5 & 6.0 & 8.0 \\
6 & 6.0 & 4.0 \\
7 & 8.0 & 6.0 \\
8 & 8.0 & 10.0 \\
\hline
\end{tabular}

In the nutrient effects experiments, the light intensity was approximately 4000 lux for $24 \mathrm{~h}$ a day, and the culture temperature was $23.2 \pm 2{ }^{\circ} \mathrm{C}$. Each set of samples was performed in triplicate.

\subsubsection{The Effect of Wastewater Quality and Bacteria in Actual Wastewater}

To investigate the effect of actual wastewater quality and original bacteria in wastewater on the growth of $S$. dimorphus, the effluent from the primary sedimentation tank and the secondary sedimentation tank (i.e., PT and ST) were selected for microalgae culture. Additionally, the sterilized and unsterilized groups were set, respectively. The experimental groups were PTS (PT sterilized), PTU (PT, unsterilized), STS (ST, sterilized), and STU (ST, unsterilized). The light intensity was about 4000 lux, the daily light was $24 \mathrm{~h}$, and the culture temperature was $23.2 \pm 2{ }^{\circ} \mathrm{C}$. Three replicates were set for each experimental 
group. The growth curve of $S$. dimorphus culture for 9 days and the chlorophyll a contents of the microalgae at day 4 and day 7 were determined. A repeatable two-factor ANOVA was performed.

\subsubsection{The Effect of Illumination Conditions}

The effects of light intensity and the light-dark cycle on the growth of S. dimorphus in synthetic wastewater and actual wastewater were investigated through the uniform experimental design, respectively. The experimental scheme is shown in Table 5. Different lighting intensifiers were set via the number and installation height of fluorescent lamps, at 2500 lux, 5000 lux, 7500 lux, 10,000 lux, 12,500 lux, and 15,000 lux. The daily illumination period was automatically controlled by the timing controller and set to six levels: $4 \mathrm{~h}, 8 \mathrm{~h}$, $12 \mathrm{~h}, 16 \mathrm{~h}, 20 \mathrm{~h}$, and $24 \mathrm{~h}$. The culture temperature was $23.2 \pm 2{ }^{\circ} \mathrm{C}$. Each set of samples was performed in triplicate. The growth curve of $S$. dimorphus cultured for 8 days was measured. Considering the different growth conditions of microalgae in different wastewater qualities, the cubic polynomial stepwise regression equation fitting of $\mathrm{OD}_{680}$ of microalgae cultured at day 3 in synthetic wastewater and of chlorophyll a content at day 4 in actual wastewater were conducted, respectively.

Table 5. The uniform design of the effect of light intensity and daily light period on Scenedesmus dimorphus growth.

\begin{tabular}{ccc}
\hline Group & Light Intensity (lux) & Time \\
\hline 1 & 15,000 & 12 \\
2 & 15,000 & 24 \\
3 & 12,500 & 4 \\
4 & 12,500 & 16 \\
5 & 10,000 & 8 \\
6 & 10,000 & 20 \\
7 & 7500 & 20 \\
8 & 7500 & 4 \\
9 & 5000 & 16 \\
10 & 5000 & 12 \\
11 & 2500 & 24 \\
12 & 2500 & 8 \\
\hline
\end{tabular}

\subsubsection{The Effect of $\mathrm{CO}_{2}$ Conditions}

In order to investigate the effect of $\mathrm{CO}_{2}$ on microalgae growth, three groups of experiments were set, including air, air enriched with $2 \% \mathrm{CO}_{2}(0.004 \mathrm{v} / \mathrm{v} \cdot \mathrm{min})$, and air enriched with $5 \% \mathrm{CO}_{2}(0.01 \mathrm{v} / \mathrm{v} \cdot \mathrm{min})$. The air flow rate under various conditions was controlled at $300 \mathrm{~mL} / \mathrm{min}$, and the light intensity was about 6000 lux, with a daily illumination of $24 \mathrm{~h}$. The culture temperature was set as $23.2 \pm 2{ }^{\circ} \mathrm{C}$. The growth curves of synthetic wastewater and actual wastewater cultured for five days were measured, respectively.

\section{Results and Discussion}

\subsection{The Effect of Nutrients in Synthetic Wastewater on the Growth of S. dimorphus}

The growth curves of $S$. dimorphus under different forms and concentrations of nitrogen in the synthetic wastewater are shown in Figure 1. After 3-4 days, the growth of most experimental groups of microalgae gradually slowed down and began to differentiate. Figure 2 displays the $\mathrm{OD}_{680}$ on day 4 and chlorophyll a content on day 3. Different forms of nitrogen source had a significant effect on the growth of microalgae according to $\mathrm{OD}_{680}$ $\left(p=9.59 \times 10^{-6}\right)$ and chlorophyll a content $\left(p=1.31 \times 10^{-8}\right)$. The highest specific growth rate was $0.432 \mathrm{~d}^{-1}$ at $20 \mathrm{mg} / \mathrm{L}$ of ammonia. Compared to ammonia and nitrate nitrogen, urea was more beneficial to the growth of $S$. dimorphus. The growth rate of S. dimorphus increased significantly when urea was used as a nitrogen source, while there was no significant difference in microalgal growth between the two inorganic nitrogen sources. This was similar to the findings of Campos et al. [26], who reported that Nannochloropsis 
salina achieved the maximum cell density and maximum sustainable yield in urea as the single nitrogen source compared to $\mathrm{NH}_{4} \mathrm{Cl}, \mathrm{NH}_{4} \mathrm{OH}, \mathrm{NaNO}_{3}$, and mixed nitrogen medium. However, Li et al. [19] found that the specific growth rates of Scenedesmus sp. $\mathrm{LX} 1$ cultivated with different nitrogen sources were, in descending order, $\mathrm{NH}_{4}{ }^{+}-\mathrm{N}>$ urea $>\mathrm{NO}_{3}{ }^{-}-\mathrm{N}$ when cultured with different substances as the nitrogen source. According to Arumugam et al., nitrate was the preferred nitrogen source form of S. bijugatus. This may be due to different microalgae strains using nitrogen forms with varying utilization efficiency. S. dimorphus grew best in the original synthetic wastewater, indicating that microalgae are better adapted to a mixed nitrogen source. This was similar to the findings of Mandal et al. [27], who found that the mean biomass yield of five microalgal strains cultivated in a mixed nitrogen source was $88 \%$ higher than a single species of microalgae.

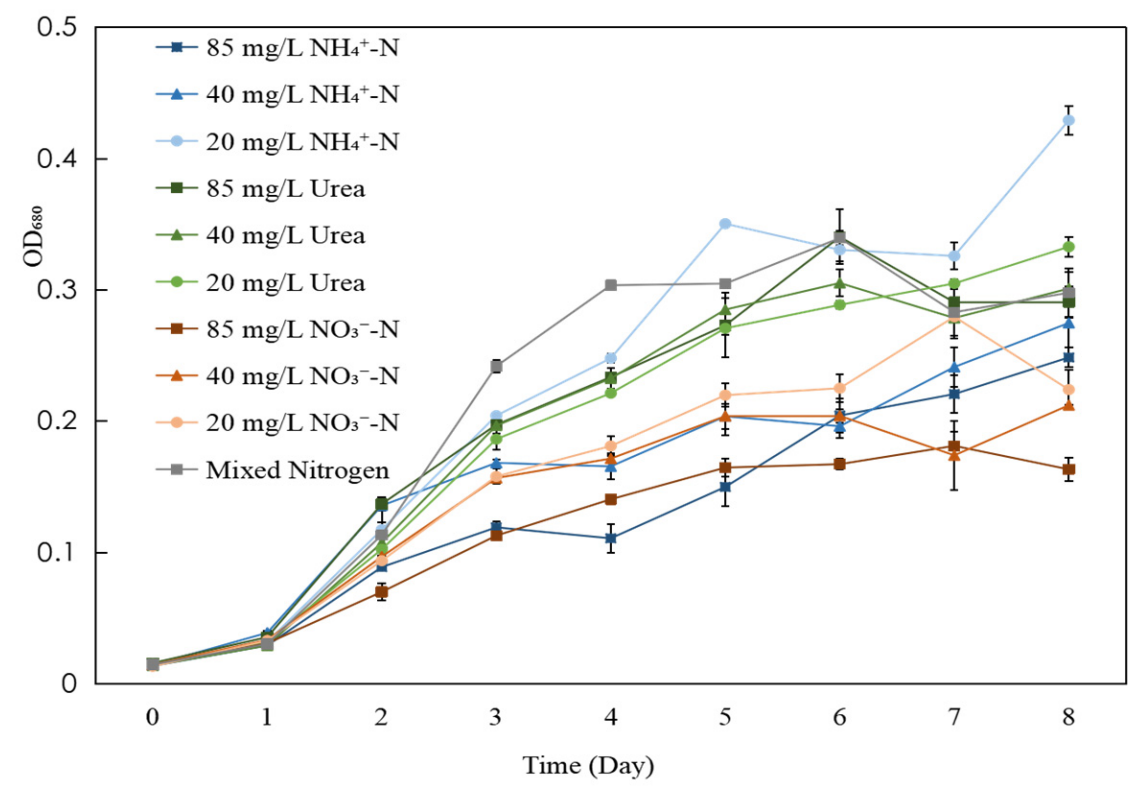

Figure 1. Growth curves of Scenedesmus dimorphus under different forms and concentrations of nitrogen sources in synthetic wastewater $(n=3)$.
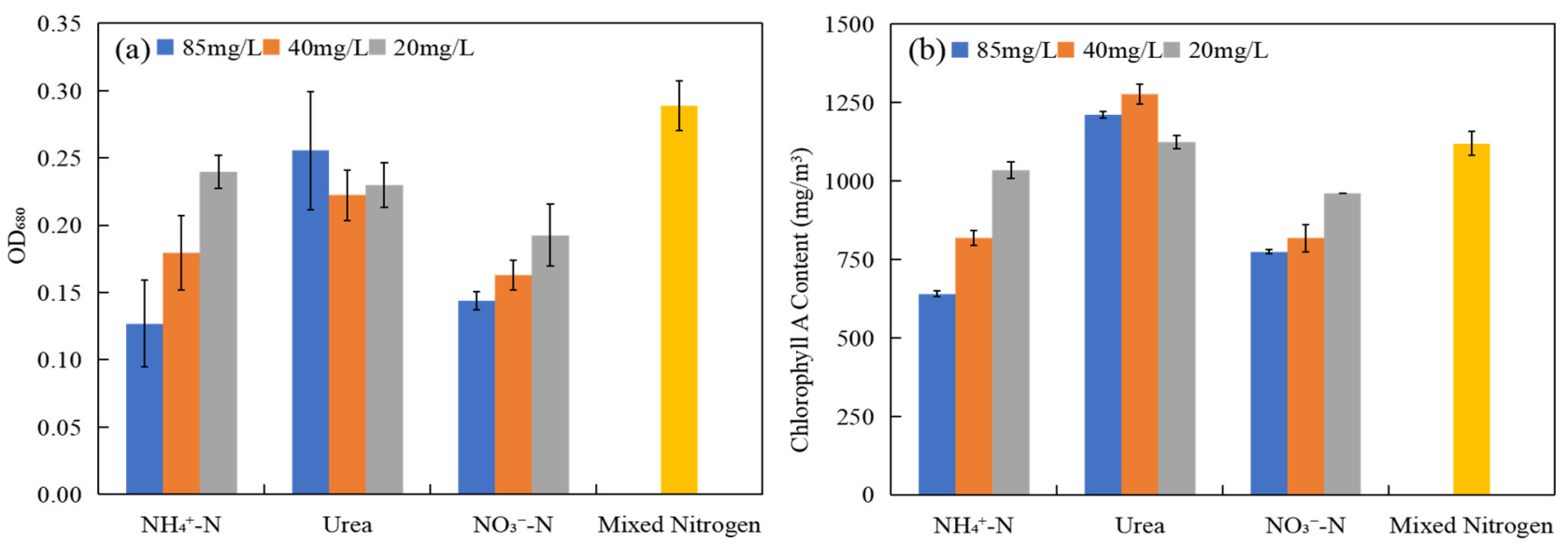

Figure 2. Growth of Scenedesmus dimorphus under different nitrogen sources and nitrogen concentrations: (a) $\mathrm{OD}_{680}$; (b) chlorophyll a content $(n=3)$.

The concentration of the nitrogen source also had a significant effect on microalgal growth according to $\operatorname{OD}_{680}(p=0.0015)$ and chlorophyll a content $\left(p=3.88 \times 10^{-5}\right)$. The results show that different concentrations of urea had little effect on the growth of S. dimorphus. For groups that utilize inorganic nitrogen, the growth rate of microalgae slowed with the concentration of ammonia nitrogen and nitrate nitrogen increasing, in- 
dicating that a high concentration of inorganic nitrogen can inhibit the growth. This may be due to the release of $\mathrm{H}^{+}$from $\mathrm{NH}_{4}{ }^{+}$in the process of microalgae culture, which reduces the $\mathrm{pH}$ value of the aquatic environment and affects the growth of microalgae [28]. Arumugam et al. found that there was an interaction between the species and concentration of nitrogen sources on the growth of microalgae. When using urea, nitrate, and ammonium as nitrogen sources, the growth of microalgae showed no differences under low-concentration conditions [19].

The uniform experimental design results of $S$. dimorphus cultivation with different phosphorus sources and $\mathrm{pH}$ values are shown in Figure 3a. The results illustrate that the optimum growth of S. dimorphus was obtained when phosphate was $4 \mathrm{mg} / \mathrm{L}$ and $\mathrm{pH}$ was 7 . The corresponding specific growth rate could reach $0.469 \mathrm{~d}^{-1}$. Cubic polynomial stepwise regression equation fitting was performed for $\mathrm{OD}_{680}$ on day 4 (see Equation (3)), and the contour line fitting diagram is shown in Figure $3 \mathrm{~b}$.

$Z=-4.990+1.197 X+1.067 Y-0.219 X^{2}-0.0691 Y^{2}-0.0079 X Y+0.0128 X^{3}\left(R^{2}=0.9910\right)$,

where $\mathrm{Z}$ is the $\mathrm{OD}_{680}, \mathrm{X}$ is the phosphorus concentration $(\mathrm{mg} / \mathrm{L}), \mathrm{Y}$ is the $\mathrm{pH}$, and $\mathrm{R}^{2}$ is the determinate coefficient. The results show that the growth of $S$. dimorphus was significantly affected by $\mathrm{pH}$. $\mathrm{pH}$ can change the permeability of cell membranes [29]. It can also change the morphology of phosphates, possibly forming brown deposits that inhibit microalgae photosynthesis [30]. The growth of $S$. dimorphus was inhibited under both acid and base conditions. The optimum $\mathrm{pH}$ for the growth of $S$. dimorphus is about 7.5. In the typical domestic wastewater phosphorus concentration range $(2 \mathrm{mg} / \mathrm{L}-8 \mathrm{mg} / \mathrm{L})$, the phosphorus concentration of about $4 \mathrm{mg} / \mathrm{L}$ is appropriate for microalgae growth. The increase in phosphorus concentration can inhibit the growth of algae. Sharma and Kumair reported that the dry weight of microalgae increased with a phosphate concentration increase from 0 to $250 \mathrm{mg} / \mathrm{L}$, while the concentration of phosphate increased to $300 \mathrm{mg} / \mathrm{L}$ when the dry biomass decreased [31]. In addition, there was no significant interaction between phosphorus concentration and $\mathrm{pH}$ value.
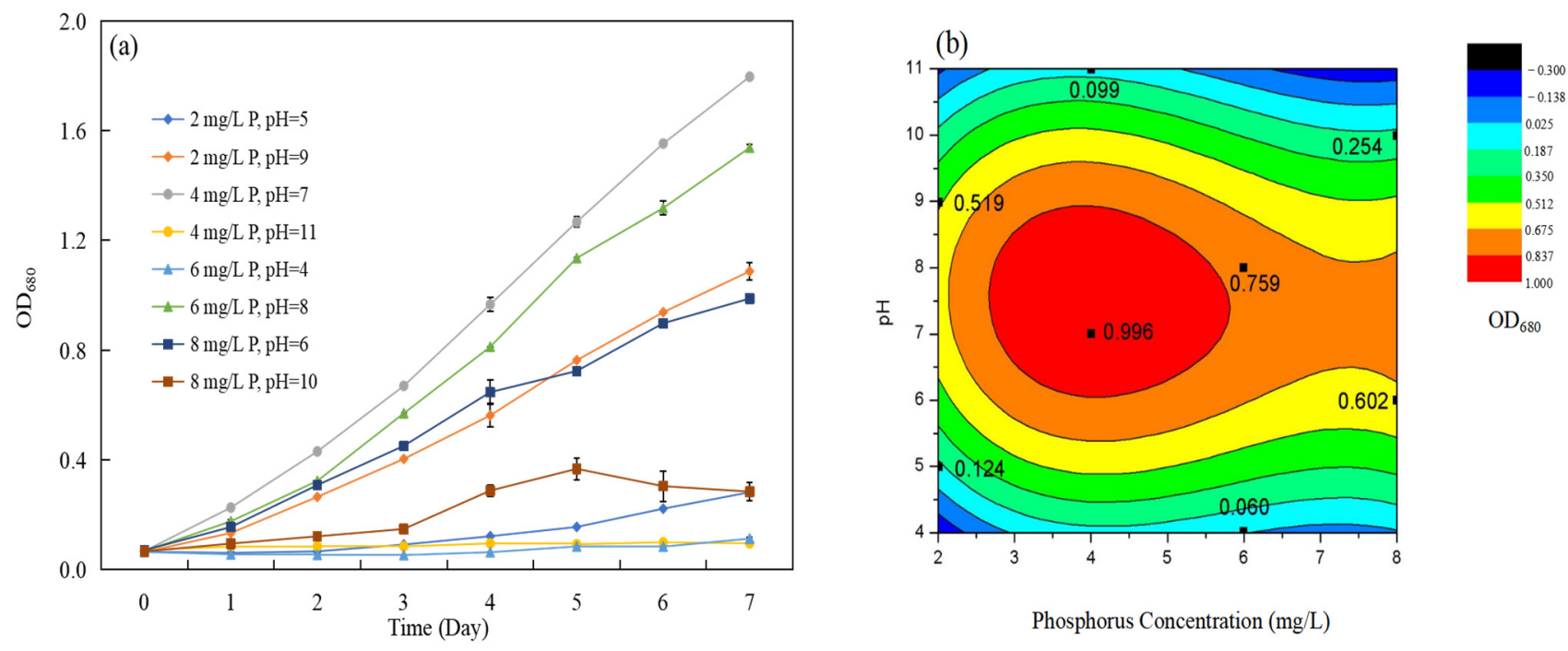

Figure 3. (a) The uniform design results under different phosphorus sources and $\mathrm{pH}$ of the effect on the growth of Scenedesmus dimorphus. (b) The contour line fitting diagram of the effect on the growth of Scenedesmus dimorphus $(n=3)$.

\subsection{The Effect of Wastewater Quality and Bacteria in Actual Wastewater on the Growth of S. dimorphus}

Figure 4a shows the curves of $\mathrm{OD}_{680}$ over time of $S$. dimorphus cultivated in wastewater of different qualities (i.e., PTS, PTU, STS, and STU), respectively. The growth trends of microalgae were similar under four wastewater quality conditions. It should be noted that the $\mathrm{OD}_{680}$ of microalgae cultured in PTU was negative on day 2. During the experiment, it 
was observed that the initial wastewater was turbid, which may be due to the presence of a large number of suspended organic substances in the primary sedimentation tank effluent. After a day of bacterial degradation, water quality became clearer, resulting in a decline in absorbance value. The phenomenon was repeated in subsequent experiments. Due to the different qualities of wastewater, the increase in absorbance in this experiment cannot fully reflect the growth of algae in the actual wastewater. Therefore, the chlorophyll a contents of $S$. dimorphus on day 4 and day 7 were determined (Figure $4 \mathrm{~b}$ ).
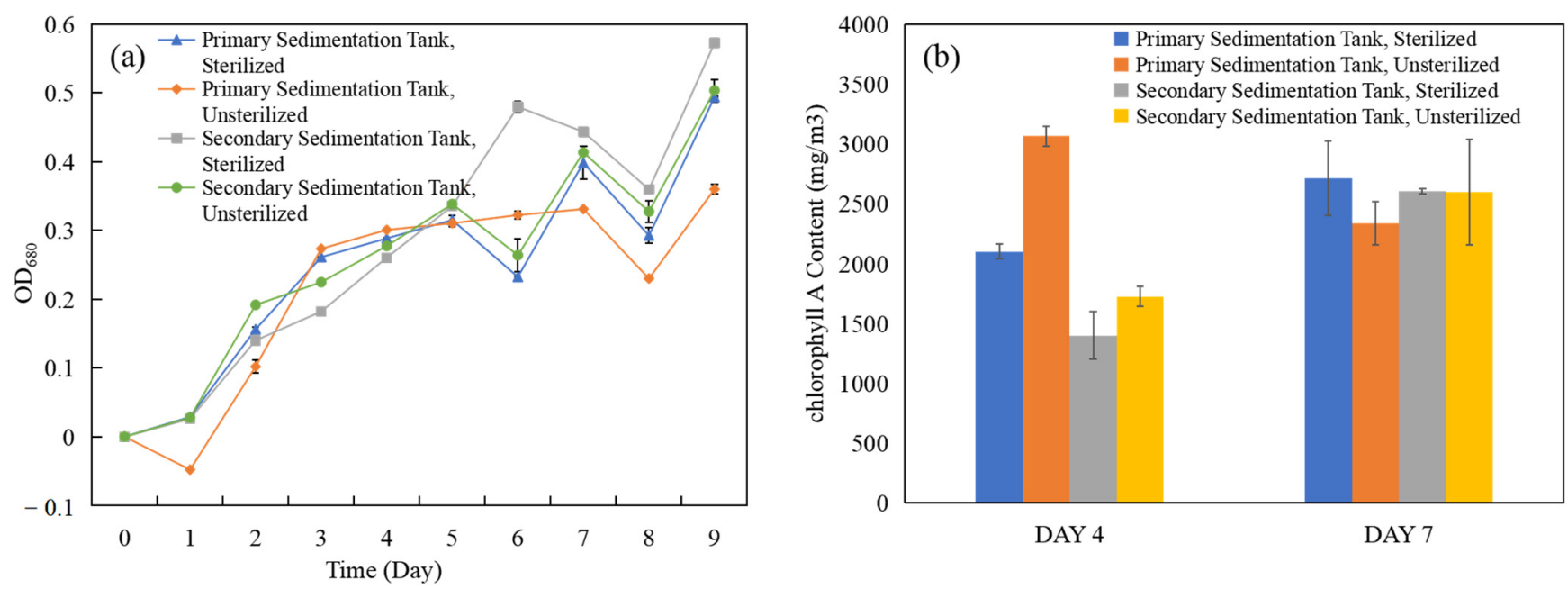

Figure 4. (a) Growth curve of Scenedesmus dimorphus under different wastewater qualities (i.e., PTS, PTU, STS, and STU) characterized by $\mathrm{OD}_{680}$. (b) The chlorophyll a content of Scenedesmus dimorphus under different wastewater qualities at day 4 and day $7(n=3)$.

On day 4 , the wastewater quality had a very significant impact on the growth of $S$. dimorphus $\left(p=4.75 \times 10^{-7}\right)$. The effluent from the PT was more suitable for the growth of microalgae than that from the ST, possibly because the nutrients in the PT were more abundant. This is consistent with the previous experimental results of nutrients in synthetic wastewater. Bacteria also had a very significant effect on the growth of algae $\left(p=1.97 \times 10^{-5}\right)$. This may be due to the interaction between the growth of bacteria and microalgae; bacteria can decompose organic nutrients into small molecular organic substances or inorganic substances that are conducive to the absorption of microalgae. Meanwhile, bacteria can degrade organic carbon in water and release $\mathrm{CO}_{2}$, which can promote the photosynthesis of microalgae [32]. The synergistic cooperation between native bacteria and microalgae increased the biomass and improved the efficiency of nutrient removal $[33,34]$. Compared with the secondary sedimentation tank, the PTS and PTU were significantly different $\left(p=5.18 \times 10^{-4}\right)$, which indicated that the effluent from the primary sedimentation tank contained more bacteria and had a more obvious promoting effect on the growth of microalgae. On day 7, there was no significant effect on chlorophyll a content under four conditions. It may be that the nutrients in the effluent from the primary sedimentation tank have already been decomposed and absorbed, and the effects of other environmental factors on $S$. dimorphus have replaced the effects of water quality and sterilization as the limiting factors for the growth of algae. The decrease in the number of bacteria also had a reduced effect on the growth of $S$. dimorphus. In addition, we observed that $S$. dimorphus cultured with PTU could easily form flocculants due to the influence of bacteria, which is more conducive to biomass harvest and recovery. This is because bacteria can induce microalgae to precipitate by adhesion or secretion of extracellular secretions [35]. Therefore, the effluent from the primary sedimentation tank was selected for the cultivation of S. dimorphus, pointing out that the microalgae treatment of wastewater has some limitations: it is affected by operating conditions and wastewater type (types of pollutants). 


\subsection{The Effect of Illumination Conditions in Synthetic and Actual Wastewater on the Growth of S. dimorphus}

The effects of light intensity and the light-dark cycle on the growth of S. dimorphus in synthetic and actual wastewater are shown in Figure 5, respectively. In the synthetic wastewater, S. dimorphus gradually reached the stable phase from day 2 , and the growth slowed down from day 3 . The time to reach the stable period of each experimental group was affected by the illumination intensity and light-dark cycle. Cubic polynomial stepwise regression equation fitting was performed for $\mathrm{OD}_{680}$ of microalgae solution cultured for day 3 (see Equation (4)). The contour line fitting diagram was shown in Figure 6a.

$$
\begin{aligned}
& Z=-1.069+0.216+0.155 Y-0.0175 X^{2}-0.00859 Y^{2}-0.00583 X Y+0.000582 X^{3}+0.000157 Y^{3}+0.000145 X Y^{2} \\
& \left(R^{2}=0.9147\right)
\end{aligned}
$$

where $\mathrm{Z}$ is the $\mathrm{OD}_{680}, \mathrm{X}$ is the light intensity $\left(10^{3} \mathrm{lux}\right), \mathrm{Y}$ is the daily light period (h), and $\mathrm{R}^{2}$ is the determinate coefficient. As shown in Figure 6a, there is a complex interaction between light intensity and illumination period on the growth of S. dimorphus. Under the condition of low light intensity and low light duration, S. dimorphus grew slowly. With the increase in light intensity and daily light time, the growth of $S$. dimorphus showed an increasing trend. However, when the light time increased to $24 \mathrm{~h}$ at the light intensity of 15,000 lux, it was not conducive to the growth of microalgae compared with the $12 \mathrm{~h}$ group. A similar situation has been widely reported in previous studies. According to Li et al. [36], the biomass of $C$. kessleri increased gradually when the light intensity increased in the range of $0-120 \mu \mathrm{mol} / \mathrm{m}^{2} \cdot \mathrm{s}$. However, when the light intensity was further increased by $200 \mu \mathrm{mol} / \mathrm{m}^{2} \cdot \mathrm{s}$, the accumulation of biomass decreased, possibly due to photoinhibition.
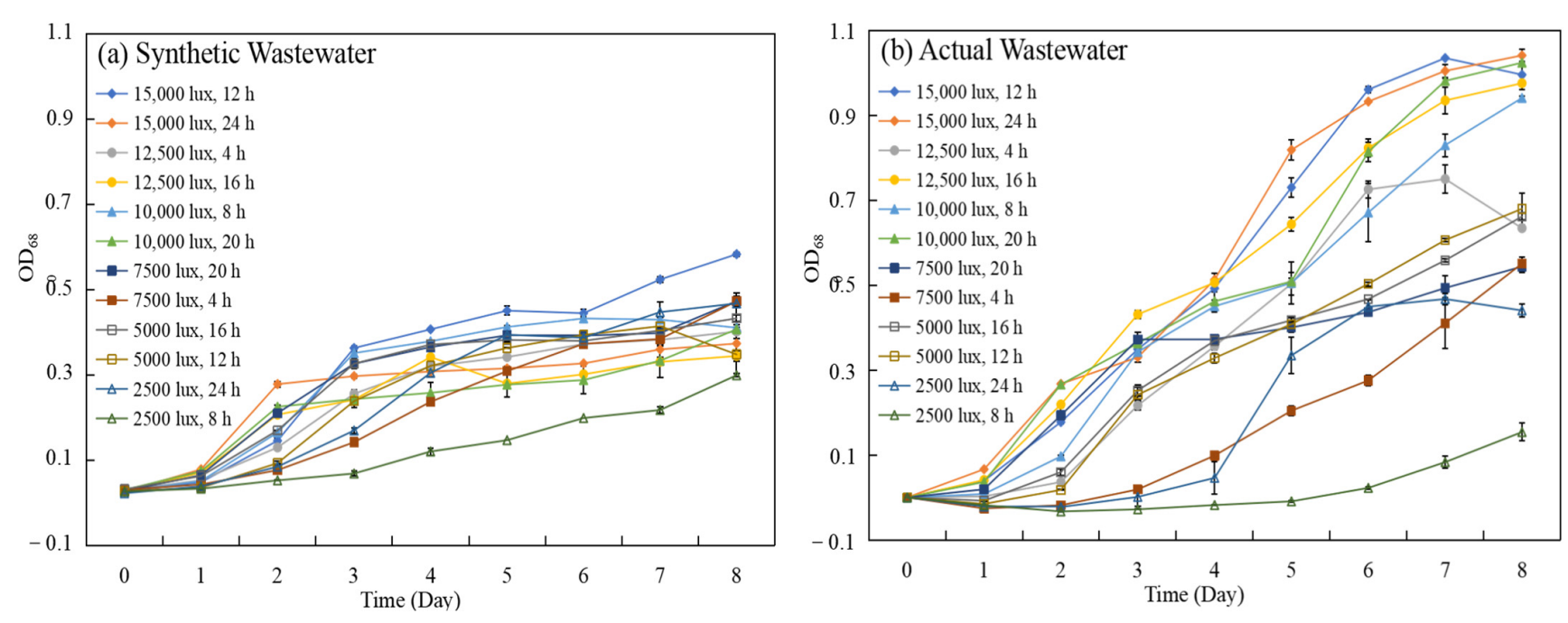

Figure 5. The uniform design results of the effect under different light intensity and daily light time on the growth of Scenedesmus dimorphus in (a) Synthetic wastewater, (b) Actual wastewater. $(n=3)$.

The growth curve of $S$. dimorphus characterized by $\mathrm{OD}_{680}$ displayed a continuous increasing trend in actual wastewater and began to differentiate on about day 4 (Figure $5 b$ ). Due to the influence of bacteria, suspended organic substances, etc., we chose the chlorophyll a content to characterize the microalgae biomass in actual wastewater. Cubic polynomial stepwise regression equation fitting was performed for chlorophyll a content for day 4 (see Equation (5)), and the contour line fitting diagram is shown in Figure $6 \mathrm{~b}$. 


$$
Z=-9686+1255 X+1513 Y-42.69 Y^{2}-124.9 X Y-2.221 X^{3}+2.078 X Y^{2}+3.197 X^{2} Y\left(R^{2}=0.9875\right)
$$

where $\mathrm{Z}$ is the chlorophyll a content $\left(\mathrm{mg} / \mathrm{m}^{3}\right), \mathrm{X}$ is the light intensity $\left(10^{3} \mathrm{lux}\right), \mathrm{Y}$ is the daily light period $(h)$, and $R^{2}$ is the determinate coefficient. It can be seen from Figure $6 \mathrm{~b}$ that in actual wastewater, there is a complex interaction between light intensity and the light cycle. Compared with synthetic wastewater, the optimal daily light period extended to about $15 \mathrm{~h}$ under the illumination intensity condition of 15,000 lux. Due to the complex composition and high turbidity in actual wastewater, the light exposure of microalgae is correspondingly reduced. Therefore, the optimum growth condition of S. dimorphus can be achieved by properly extending the daily light period in the actual wastewater condition.

(a) Synthetic Wastewater

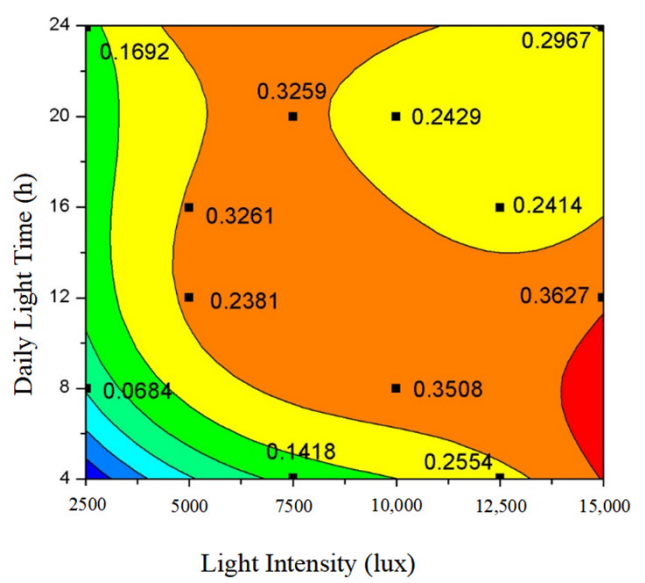

(b) Actual Wastewater

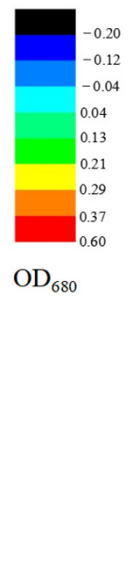

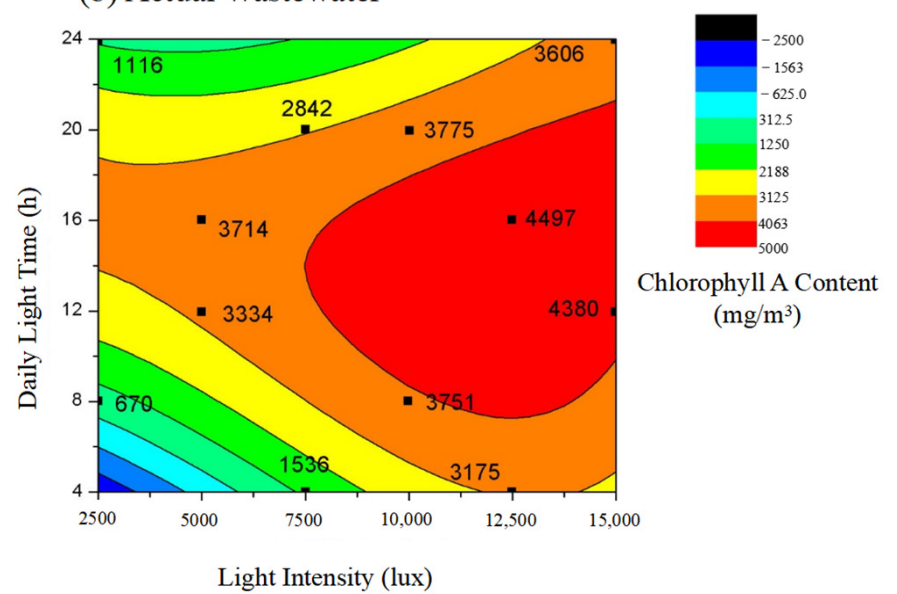

Figure 6. The contour line fitting diagram of the effect of light intensity and daily light time on the growth of Scenedesmus dimorphus: (a) characterized by $\mathrm{OD}_{680}$ in synthetic wastewater; (b) characterized by chlorophyll a content in actual wastewater $(n=3)$.

\subsection{The Effect of $\mathrm{CO}_{2}$ in Synthetic and Actual Wastewater on the Growth of S. dimorphus}

The effects of $\mathrm{CO}_{2}$ on the growth of $S$. dimorphus in synthetic wastewater and actual wastewater are shown in Figure 7. In synthetic wastewater, the growth of S. dimorphus was significantly promoted in comparison with the $2 \% \mathrm{CO}_{2}$ group, while the $5 \% \mathrm{CO}_{2}$ group showed no difference from the air group. The average specific growth rate was 0.683 in the $2 \% \mathrm{CO}_{2}$ group. As shown in Figure $7 \mathrm{~b}$, the growth of $S$. dimorphus in the $\mathrm{CO}_{2}$-enriched group was much greater than that in the air group cultivated in actual wastewater. After 4-7 days of culture, the growth of microalgae in the $2 \% \mathrm{CO}_{2}$ group was the fastest. There was no significant difference between the growth rate of the $2 \%$ and $5 \% \mathrm{CO}_{2}$ groups $(p=0.9206)$. The specific growth rate was around $0.279-0.309$ in these three groups. It can be found that the growth curve of $S$. dimorphus reached its peak when the air was enriched with $2 \% \mathrm{CO}_{2}$ in both kinds of wastewater. The final biomass characterized by $\mathrm{OD}_{680}$ in actual wastewater was less than that in synthetic wastewater. Goncalves et al. [21] reported four microalgae strains that achieved the highest biomass yield $(0.126 \mathrm{~g} \mathrm{dw} / \mathrm{L} \cdot \mathrm{d})$ and carbon fixation rate $(0.101 \mathrm{~g} \mathrm{c} / \mathrm{L} \cdot \mathrm{d})$ with a range up to $10 \% \mathrm{CO}_{2}$. The optimum $\mathrm{CO}_{2}$ concentration was calculated as 5.35\%. Razzak et al. [37] also reported that the $4 \% \mathrm{CO}_{2}$ can recover the maximum biomass production in the cultivation of Chlorella sp. among $2-12 \% \mathrm{CO}_{2}$. This indicated that adding $\mathrm{CO}_{2}$ of low concentration can greatly promote the growth of microalgae. The different optimum $\mathrm{CO}_{2}$ concentrations may be due to the different microalgae species in the literature compared with this study. 

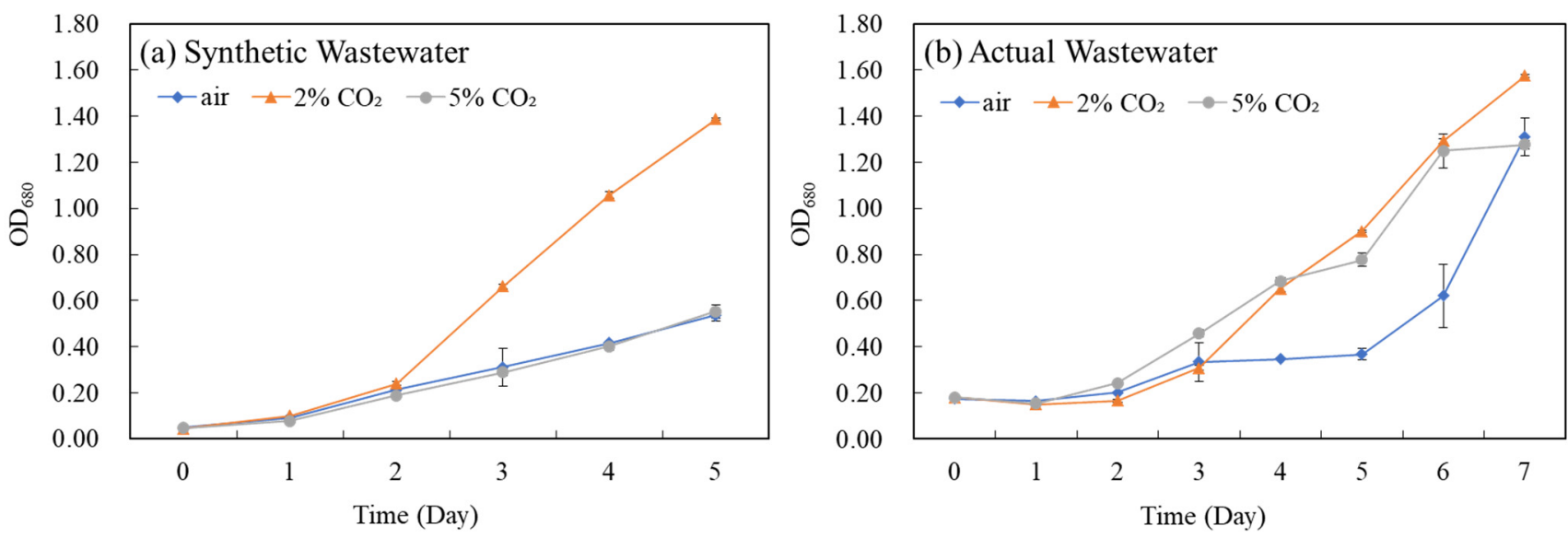

Figure 7. Growth curve of Scenedesmus dimorphus under different $\mathrm{CO}_{2}$ concentrations in (a) synthetic wastewater and (b) actual wastewater $(n=3)$.

\section{Conclusions}

From this study, the following conclusions can be made:

(1) When urea was used as a nitrogen source, the growth of $S$. dimorphus was increased. The high concentration of inorganic nitrogen (ammonia nitrogen and nitrate nitrogen) could inhibit the growth of $S$. dimorphus.

(2) The growth of $S$. dimorphus reached its highest when phosphate was $4 \mathrm{mg} / \mathrm{L}$ and the $\mathrm{pH}$ was 7.

(3) The bacteria in actual sewage can promote the growth of microalgae and facilitate biomass harvest.

(4) Under the condition of an illumination intensity of 15,000 Lux, when the optimal daily illumination time was about $15 \mathrm{~h}$, the growth of $S$. dimorphus in actual sewage was optimum.

(5) When adding $2 \%(0.004 \mathrm{v} / \mathrm{v} \cdot \mathrm{min}) \mathrm{CO}_{2}$, the growth of $S$. dimorphus was the best in both synthetic and actual wastewater.

Author Contributions: Conceptualization, L.L. and K.C.; methodology, K.C.; software, K.C.; validation, L.L. and K.C.; formal analysis, K.C.; investigation, L.L.; resources, K.C.; data curation, K.C.; writing-original draft preparation, K.C.; writing—review and editing, L.L.; visualization, K.C.; supervision, L.L.; project administration, L.L.; funding acquisition, L.L. All authors have read and agreed to the published version of the manuscript.

Funding: This research received no external funding.

Institutional Review Board Statement: Not applicable.

Informed Consent Statement: Not applicable.

Data Availability Statement: Not applicable.

Conflicts of Interest: The authors declare no conflict of interest.

\section{References}

1. Munir, A.; Hanjraa, J.B.G.C. Wastewater irrigation and environmental health Implications for water governance and public policy. Int. J. Hyg. Environ. Health 2012, 215, 255-269.

2. Hu, K.; Zhao, Q.L.; Chen, W.; Wang, W.; Han, F.; Shen, X.H. Appropriate technologies for upgrading wastewater treatment plants: Methods review and case studies in China. J. Environ. Sci. Health Part A Toxic/Hazard. Subst. Environ. Eng. 2018, 53, 1207. [CrossRef] [PubMed]

3. Chaudhary, R.; Tong, Y.W.; Dikshit, A.K. $\mathrm{CO}_{2}$-assisted removal of nutrients from municipal wastewater by microalgae Chlorella vulgaris and Scenedesmus obliquus. Int. J. Environ. Sci. Technol. 2018, 15, 2183. [CrossRef]

4. Mehariya, S.; Goswami, R.K.; Verma, P.; Lavecchia, R.; Zuorro, A. Integrated Approach for Wastewater Treatment and Biofuel Production in Microalgae Biorefineries. Energies 2021, 14, 2282. [CrossRef] 
5. Tan, F.; Wang, Z.; Zhouyang, S.; Li, H.; Xie, Y.; Wang, Y.; Zheng, Y.; Li, Q. Nitrogen and phosphorus removal coupled with carbohydrate production by five microalgae cultures cultivated in biogas slurry. Bioresour. Technol. 2016, 221, 385. [CrossRef]

6. Saavedra, R.; Munoz, R.; Taboada, M.E.; Vega, M.; Bolado, S. Comparative uptake study of arsenic, boron, copper, manganese and zinc from water by different green microalgae. Bioresour. Technol. 2018, 263, 49. [CrossRef] [PubMed]

7. Zuorro, A.; Lavecchia, R.; Maffei, G.; Marra, F.; Miglietta, S.; Petrangeli, A.; Familiari, G.; Valente, T. Enhanced Lipid Extraction from Unbroken Microalgal Cells Using Enzymes. In Proceedings of the Icheap12: 12th International Conference On Chemical \& Process Engineering, Milano, Italy, 19-22 May 2015; Volume 43, pp. 211-216.

8. Li, F.; Yang, Z.; Zeng, R.; Yang, G.; Chang, X.; Yan, J.; Hou, Y. Microalgae capture of $\mathrm{CO}_{2}$ from actual flue gas discharged from a combustion chamber. Ind. Eng. Chem. Res. 2011, 50, 6496. [CrossRef]

9. Molitor, H.R.; Moore, E.J.; Schnoor, J.L. Maximum $\mathrm{CO}_{2}$ utilization by nutritious microalgae. ACS Sustain. Chem. Eng. 2019, 7, 9474. [CrossRef]

10. Roberts, G.W.; Fortier, M.P.; Sturm, B.S.M.; Stagg-Williams, S.M. Promising pathway for algal biofuels through wastewater cultivation and hydrothermal conversion. Energy Fuels 2013, 27, 857. [CrossRef]

11. Carvalho, A.R.; Perez-Pereira, A.I.; Couto, C.M.C.; Tiritan, M.E.; Ribeiro, C.M.R. Assessment of effluents quality through ecotoxicological assays: Evaluation of three wastewater treatment plants with different technologies. Environ. Sci. Pollut. Res. Int. 2021. [CrossRef]

12. Diniz, G.S.; Silva, A.F.; Araujo, O.Q.F.; Chaloub, R.M. The potential of microalgal biomass production for biotechnological purposes using wastewater resources. J. Appl. Phycol. 2017, 29, 821. [CrossRef]

13. Li, Y.; Tarpeh, W.A.; Nelson, K.L.; Strathmann, T.J. Quantitative evaluation of an integrated system for valorization of wastewater algae as bio-oil, fuel gas, and fertilizer products. Environ. Sci. Technol. 2018, 52, 12717. [CrossRef]

14. Goswami, R.K.; Mehariya, S.; Verma, P.; Lavecchia, R.; Zuorro, A. Microalgae-based biorefineries for sustainable resource recovery from wastewater. J. Water Process. Eng. 2021, 40, 101747. [CrossRef]

15. Zhuang, L.; Yu, D.; Zhang, J.; Liu, F.; Wu, Y.; Zhang, T.; Dao, G.; Hu, H. The characteristics and influencing factors of the attached microalgae cultivation: A review. Renew. Sustain. Energy Rev. 2018, 94, 1110. [CrossRef]

16. Ma, X.; Zhou, W.; Fu, Z.; Cheng, Y.; Min, M.; Liu, Y.; Zhang, Y.; Chen, P.; Ruan, R. Effect of wastewater-borne bacteria on algal growth and nutrients removal in wastewater-based algae cultivation system. Bioresour. Technol. 2014, 167, 8. [CrossRef]

17. Sayara, T.; Khayat, S.; Saleh, J.; Abu-Khalaf, N.; van der Steen, P. Algal-bacterial symbiosis for nutrients removal from wastewater: The application of multivariate data analysis for process monitoring and control. Environ. Technol. Innov. 2021, $23,101548$. [CrossRef]

18. Annelies, B.; Erik, S.; Koenraad, M. Nitrogen availability influences phosphorus removal in microalgae-based wastewater treatment. Water Res. 2015, 77, 98-106.

19. Arumugam, M.; Agarwal, A.; Arya, M.C.; Ahmed, Z. Influence of nitrogen sources on biomass productivity of microalgae Scenedesmus bijugatus. Bioresour. Technol. 2013, 131, 246. [CrossRef]

20. Coleman, J.R. The molecular and biochemical analyses of $\mathrm{CO}_{2}$-concentrating mechanisms in cyanobacteria and. Plant Cell Environ . 1991, 14, 861. [CrossRef]

21. Goncalves, A.L.; Rodrigues, C.M.; Pires, J.C.M.; Simoes, M. The effect of increasing $\mathrm{CO}_{2}$ concentrations on its capture, biomass production and wastewater bioremediation by microalgae and cyanobacteria. Algal Res. 2016, 14, 127. [CrossRef]

22. Ho, S.; Chen, C.; Chang, J. Effect of light intensity and nitrogen starvation on $\mathrm{CO}_{2}$ fixation and lipid/carbohydrate production of an indigenous microalga Scenedesmus obliquus CNW-N. Bioresour. Technol. 2012, 113, 244. [CrossRef] [PubMed]

23. Lee, C.S.; Lee, S.; Ko, S.; Oh, H.; Ahn, C. Effects of photoperiod on nutrient removal, biomass production, and algal-bacterial population dynamics in lab-scale photobioreactors treating municipal wastewater. Water Res. 2015, 68, 680. [CrossRef] [PubMed]

24. Ruiz-Marin, A.; Mendoza-Espinosa, L.G.; Stephenson, T. Growth and nutrient removal in free and immobilized green algae in batch and semi-continuous cultures treating real wastewater. Bioresour. Technol. 2010, 101, 58. [CrossRef]

25. Arvin, E. The influence of $\mathrm{pH}$ and calcium ions upon phosphorus transformations in biological wastewater treatment plants. Prog. Wat. Tech. 1979, S1, 19-40.

26. Campos, H.; Boeing, W.J.; Dungan, B.N.; Schaub, T. Cultivating the marine microalga Nannochloropsis salina under various nitrogen sources: Effect on biovolume yields, lipid content and composition, and invasive organisms. Biomass Bioenergy 2014, 66, 301. [CrossRef]

27. Mandal, S.; Shurin, J.B.; Efroymson, R.A.; Mathews, T.J. Heterogeneity in Nitrogen Sources Enhances Productivity and Nutrient Use Efficiency in Algal Polycultures. Environ. Sci. Technol. 2018, 52, 3769. [CrossRef] [PubMed]

28. Li, X.; Hu, H.; Gan, K.; Yang, J. Growth and nutrient removal properties of a freshwater microalga Scenedesmus sp LX1 under different kinds of nitrogen sources. Ecol. Eng. 2010, 36, 379.

29. Lavoie, M.; Le Faucheur, S.; Boullemant, A.; Fortin, C.; Campbell, P.G.C. The influence of pH on algal cell membrane permeabrane permeability and its implications for the uptake of lipophilic metal. J. Phycol. 2012, 48, 293. [CrossRef]

30. Acuna-Alonso, C.; Lorenzo, O.; Alvarez, X.; Cancela, A.; Valero, E.; Sanchez, A. Influence of Microcystis sp. and freshwater algae on $\mathrm{pH}$ : Changes in their growth associated with sediment. Environ. Pollut. 2020, 263, 114435. [CrossRef]

31. Sharma, V.K.; Kumar, H.D. Influence of $\mathrm{pH}$ and concentration of phosphare ions on growth-fixation in a blue-green-alga cylindrospermum-maus. Experientia 1975, 31, 182. [CrossRef] 
32. Liu, H.; Lu, Q.; Wang, Q.; Liu, W.; Wei, Q.; Ren, H.; Ming, C.; Min, M.; Chen, P.; Ruan, R. Isolation of a bacterial strain, Acinetobacter sp from centrate wastewater and study of its cooperation with algae in nutrients removal. Bioresour. Technol. 2017, 235, 59. [CrossRef] [PubMed]

33. Su, Y.; Mennerich, A.; Urban, B. Municipal wastewater treatment and biomass accumulation with a wastewater-born and settleable algal-bacterial culture. Water Res. 2011, 45, 3351. [CrossRef] [PubMed]

34. Kumar, A.; Ergas, S.; Yuan, X.; Sahu, A.; Zhang, Q.; Dewulf, J.; Malcata, F.X.; van Langenhove, H. Enhanced $\mathrm{CO}_{2}$ fixation and biofuel production via microalgae: Recent developments and future directions. Trends Biotechnol. 2010, 28, 371. [CrossRef] [PubMed]

35. Justine, S.V.E.; Yuzhu, W.; Katja, C.F.G.; Edwin, M.F.; AlberTinka, J.M. Oil spill dispersants induce formation of marine snow by phytoplankton-associated bacteria. Mar. Pollut. Bull. 2016, 104, 294-302.

36. Li, Y.; Zhou, W.; Hu, B.; Min, M.; Chen, P.; Ruan, R.R. Effect of light intensity on algal biomass accumulation and biodiesel production for mixotrophic strains Chlorella kessleri and Chlorella protothecoide cultivated in highly concentrated municipal wastewater. Biotechnol. Bioeng. 2012, 109, 2222. [CrossRef]

37. Razzak, S.A.; Hossain, M.M.; Lucky, R.A.; Bassi, A.S.; de Lasa, H. Integrated $\mathrm{CO}_{2}$ capture, wastewater treatment and biofuel production by microalgae culturing-A review. Renew. Sustain. Energy Rev. 2013, 27, 622. [CrossRef] 